\title{
TAVSHEDENS KONSEKVENSER
}

Tyrkiske kvinders oplevelser af vold i førægteskabelige parforhold

\author{
IDA TAFDRUP-JOHANSEN
}

Under mit feltarbejde i 2010 om førægteskabelig sex blandt ugifte kvinder i Tyrkiet stødte jeg på uventet mange historier om frygt, vold og social kontrol. Historierne kom frem, i forbindelse med at informanterne fortalte om deres tidligere og daværende parforhold og seksuelle relationer. Informanterne havde kun fortalt ganske få personer om episoderne, da de ikke følte, at de kunne tale om disse aspekter af deres liv. Disse episoder er omdrejningspunktet i denne artikel, og selvom ikke alle parforhold, som mine informanter har været i, er forbundet med vold, viser analysen, at tyrkiske kvinder, der indleder seksuelle forhold før ægteskab, er potentielle ofre for udnyttelse.

Kvindens rolle i det tyrkiske samfund har været på den politiske dagsorden, siden Tyrkiet blev oprettet i 1923, men først i 1980'erne blussede en egentlig kvindekamp op. Kvinderettighedsaktivister og -organisationer arbejdede hårdt for at ændre kvinders rettigheder, og i 2001 og 2004 blev henholdsvis civilloven og straffeloven ændret, så der på juridisk plan blev taget afgørende skridt mod lighed mellem kønnene (Danneskiold-Samsøe, Mørck \& Sørensen 2011:3701). Den politiske bevågenhed til trods dokumenterer flere studier dog, at en omfattende diskrimination af kvinder stadig finder sted i Tyrkiet (HRW 2011; WWHR 2010). Mange studier (fx Parla 2001; Saktanber 1995; WWHR 2010; Ilkkaracan 2001) beskæftiger sig med køn i Tyrkiet og bekræfter diskriminationen ved at vise, at familiens ære er knyttet til kvindens seksuelle ærbarhed, hvilket betyder, at kvindens mødom skal være intakt på bryllupsnatten. Der eksisterer derfor en moralsk norm om, at kvinder ikke skal have sex før ægteskab. Et brud hermed har konsekvenser for både kvinden selv og hendes familie, og mange aktører - såsom familiemedlemmer, partnere, læger, politikker - forsøger at kontrollere kvinders seksuelle adfærd. Mødommen er derfor blevet betegnet som et socialt fænomen (Cindoglu 1997), og kvinder, hvis seksuelle praksisser bryder med de moralske normer, er omgærdet af tavshed. Ud over mit eget studie 
har jeg kun kendskab til ét andet kvalitativt studie og intet kvantitativt studie, som undersøger ugifte tyrkiske kvinders erfaringer med førægteskabelig sex. Det kvalitative studie er foretaget af den tyrkiske sociolog Gül Özyegin (2009), der ligesom jeg har foretaget feltarbejde blandt universitetsstuderende, som tilhører den urbane, vestligt orienterede overklasse i Istanbul. I Özyegins (2009) og i mit studie (2011) synes de moralske normer at blive udfordret i en grad, der ikke kommer til udtryk i tidligere studier. I disse ungdomsmiljøer er det normen at være seksuelt aktiv, og der er ligefrem tale om en forventning om at være seksuelt aktiv. I andre miljøer kan de unge kvinder dog sjældent give disse sider af deres ungdomsliv til kende, og de lever derfor med hemmeligheder og løgne.

I denne artikel argumenterer jeg for, at den tavshed, der omgiver førægteskabelig kvindelig seksualitet, medfører, at unge seksuelt aktive kvinder står i en sårbar situation, og konsekvenserne heraf kan være vold af både fysisk og psykisk karakter.

\section{Metode og informanter}

Mit feltarbejde bestod af fire måneders etnografiske feltstudier i 2010 i Istanbul, hvor jeg samlede materiale til mit speciale om seksualitet og parforhold blandt ugifte, seksuelt aktive kvinder. ${ }^{1}$ Mit primære materiale bestod af deltagerobservation $\mathrm{i}$ et universitetsmiljø, hvorfra jeg skabte god kontakt til 15 primære informanter, som jeg interviewede. Udgangspunktet for mit studie var fire gode veninder. Derfra brugte jeg sneboldmetoden til at skaffe yderligere 11 informanter. Flere af informanterne kendte derfor hinanden, og nogle af dem mødte jeg mange gange, men andre mødtes jeg kun med en enkelt gang.

Kvinderne var 20-30 år, og de er typisk opvokset i middelklasse- eller øvre middelklassehjem i Istanbul, Izmir eller omegn. De fleste er vokset op i en familie med begge forældre på arbejdsmarkedet og én søster eller bror. Alle var studerende eller havde studeret på et universitet $\mathrm{i}$ Istanbul. Da interviewene blev afviklet, boede alle informanterne i Istanbul, seks sammen med deres forældre, seks sammen med en søster, veninde eller kæreste, og tre boede alene. Alle var seksuelt aktive, ${ }^{2}$ og på interviewtidspunktet havde ti af kvinderne en kæreste (for flere detaljer, se Tafdrup 2011:17-20).

Kvinderne havde deres seksuelle debut mellem 13 og 23 år, de fleste som 1719-årige. Dette er en smule lavere, end hvad andre studier af gennemsnitsalderen for den seksuelle debut blandt seksuelt aktive kvindelige universitetsstuderende viser. De viser nemlig et gennemsnit på 19,22 og 20,77 år (Ozan et al. 2005; Yasan et al. 2009). Fordi antallet af informanter i mit studie er lavt, er sammenligningen med gennemsnitsalderen i andre studier noget svag, men det antyder, at mine 
informanter har haft deres seksuelle debut tidligt. Flere informanter giver da også udtryk for at have været nogle af de første blandt deres venner. Generelt er de vokset op i et ungdomsmiljø med massiv forventning om at være seksuel aktiv. Dette var en forventning, som de både havde til sig selv, og som de blev mødt med i deres venskabsgrupper. 23-årige Gülşa forklarede mig det således:

Da jeg var 16, begyndte mine venner at have seksuelle forhold, intenst. Jeg var den, der var jomfru. Så jeg tænkte, 'jeg må gøre noget øjeblikkeligt’. Jeg forsøgte at finde en fyr at have sex med, og jeg ville ikke fortælle ham, at jeg var jomfru. Fordi - vi lavede sjov med seksualitet, og du ville være uden for gruppen ... folk, drenge talte om mig som en ikke-jomfru, fordi jeg var sammen med venner og talte om sex. Jeg var for liberal sammenlignet med andre piger. De forventede ikke, at jeg var jomfru.

Gülşa henviser til sig selv som „for liberal til at være jomfru“. Dette skal ikke forstås som en politisk liberalisme. Derimod pointerer Gülşa vigtigheden af seksualitet som markør for et gruppetilhørsforhold. Overordnet betegner informanterne deres seksualitet med ord som „moderne“, „fri“ og „liberal“, og jeg har valgt at bruge betegnelsen ,liberal seksualitet“. Praktiseringen af en liberal seksualitet var en måde at blive en del af og udtrykke forhold til en veluddannet, vestlig orienteret overklasse. I ungdomsmiljøet var det accepteret og forventet, at man havde seksuelle relationer, og der blev talt om seksualitet, dog uden for mange personlige detaljer. Der var således tale om en seksuel praksis, der var i modsætning til de moralske normer om ærbarhed som dominerede andre sfærer i de unges liv, fx i familien (Tafdrup 2011:26-45).

De fortællinger, som er i fokus her, er fortællinger, som jeg har fået uden at have søgt efter dem. Min intention med feltarbejdet var ikke at undersøge vold i parforhold, men fortællingerne dukkede op, når informanterne fortalte retrospektivt om tidligere parforhold. Eksemplerne omhandler forskellige typer vold: fysisk vold, seksuel vold og psykisk vold i form af trusler, bebrejdelse, moralske dilemmaer og social kontrol. Eksempler på fysisk og seksuel vold er meget begrænsede, mens psykisk vold i forskellige former er mere fremtrædende. Særligt social kontrol ses mange steder i materialet, og det er også her, artiklen tager sit udgangspunkt.

\section{Social kontrol}

Informanterne talte sjældent direkte om social kontrol. Derimod talte ti af dem om jalousi og de konsekvenser, jalousi havde for parforhold. Jalousi skal ikke forstås som synonym med social kontrol, men ofte kan jalousi medfører social 
kontrol. Min gode veninde og senere informant 27-årige Leyla kan illustrere dette. Leyla var en af de informanter, jeg kendte bedst. Jeg kendte hendes veninder, jeg kendte hendes kæreste, og jeg vidste, at han konstant ringede til Leyla, når hun var ude, for at tjekke, hvor hun var, og hvem hun var sammen med. Hendes kæreste brød sig ikke om, at hun gik til fester, hvor der var mænd til stede, og han ville altid høre om detaljer dagen efter, hvis hun havde været til en sådan. Disse detaljer kunne han finde på at efterprøve ved at spørge mig eller en anden, der havde været med. Flere gange oplevede jeg Leyla grædende fortælle om et stort skænderi, de havde haft, fordi han var så kontrollerende. Helt galt var det en dag, hvor han havde fundet hendes dagbog, læst den og udspurgt hende om en lang række personer og hændelser. Leyla kom ikke ind på disse sider af sin kæreste under interviewet, men nævnte det blot som: „Jeg forelskede mig, men han var så jaloux. Det er han stadig, helt generelt. Men ellers er han god til alting: sex, parforhold, som ven. Og han er meget lækker.“

Kontrollen beskrives således ikke direkte, når den er en del af hverdagen, men den bliver tydelig, når man ser nærmere på konsekvenserne af mændenes jalousi. Informanterne beskrev jalousi som et udtryk for kærlighed og derfor noget, som de forventede af en kæreste. Ordet jalousi brugte de om en konstant opmærksomhed mod, hvem kæresten var sammen med, og hvad kæresten lavede. Dette var noget, både kvinderne selv og deres partnere praktiserede, særligt via mobiltelefoner. Seks af informanterne fortalte dog om forhold, hvor jalousien udviklede sig til en situation, hvor kæresten ville bestemme, hvem de måtte ses med. Det fortalte eksempelvis 26-årige Elif. Som 23-årig arbejdede Elif som assistent på forskellige filmoptagelser. Under en optagelse, der foregik i et bjergområde uden for Istanbul, fandt hun sammen med en 25-årig kameramand. Optagelserne varede 14 dage, og forholdet var godt i de isolerede omgivelser i bjergene:

Alle vidste, at jeg var sammen med ham. Ingen kunne se mig som et seksuelt objekt, som en vare, fordi jeg var hans. Alting var fint. Efter at vi vendte tilbage til Istanbul, så han, at jeg havde et liv her. Jeg havde venner, og de fleste var drenge. Så han blev vildt sur. Nogle gange ringede drengene til mig, og han var altid sådan - prøvede altid at overhøre samtalen. Så han forbød mig at snakke med mine drengevenner. Og jeg sagde ja. Jeg ved ikke, hvorfor jeg sagde ja. Jeg slettede alle mine drengevenners telefonnumre på min telefon.

Elif forstår ikke, hvordan hun gik med til at slette alle kontakterne til sine mandlige venner, men at hun gjorde det, illustrerer den normalisering, der skete af den sociale kontrol, som hendes kæreste udviste. Elif fortæller videre, at kæresten en dag slog hende midt under en filmoptagelse $i$ alles påsyn. Hun fortæller, hvordan hun var i chok og aldrig havde troet, at nogen skulle slå hende. Men mest af alt fortæller hun om den skam, hun følte, fordi deres kollegaer havde set det. Selvom 
Elif dengang og retrospektivt føler dyb afsky for fysisk vold, afbrød hun ikke forholdet. Slaget var en del af den kontrol, kæresten havde over hendes liv, og hun forstod sig selv og sit liv i relation til ham. Denne accept af volden kan forstås ud fra den svenske sociolog Eva Lundgrens analyse af volds normaliseringsproces. Lundgren skriver, at vold ofte opleves som uacceptabelt til at begynde med, men at regelmæssig udsættelse for vold kan bevirke, at volden normaliseres i et omfang, hvor den både forventes, accepteres og endda retfærdiggøres (Lundgren 2004:49-72).

Elif beretter ikke, hvorvidt hun blev slået sidenhen, men hun beskriver, hvordan den sociale kontrol blev mere omfattende, da hun i hast skulle finde en ny lejlighed at bo i: ,Jeg havde ingen penge, så han sagde, at jeg kunne låne nogle af ham og betale tilbage senere ... Så vi lejede en lejlighed sammen. Det var i kælderen, uden sol, med kun ét vindue. Vi begyndte at bo der sammen." I den nye lejlighed var der intet internet, og hver gang kæresten skulle på arbejde, låste han Elif inde i lejligheden: „Jeg kunne ikke ses med nogen af mine venner. Han holdt mig indespærret i huset, købte dvd'er til mig. Vi var sammen hele tiden og så [den amerikanske tv-serie] 'Lost'. Det var vores liv.“ 'Den sociale kontrol ledte ikke kun til isolation, da hun ikke kunne ses med sine venner, men altså også til frihedsberøvelse.

Den stigende normalisering af social kontrol, der havde fundet sted, Elifs langvarige accept af kærestens dominans samt hendes frygt for, at han ville slå hende igen, betød, at hun ikke ydede nogen særlig modstand mod de forhold, som hun levede under:

Men efter en tid gik det op for mig, at han var en virkelig, virkelig dårlig person. Han begyndte at sige, at jeg ikke kunne besøge min tante, fordi min onkel var i huset. Jeg ved ikke - han syntes sikkert, jeg var den smukkeste person i verden, så enhver anden mand ville forsøge at have et seksuelt forhold til mig. Men det er ikke sandt. Jeg kender mig selv og forstår, hvad der foregår. Efter han sagde det med min onkel, tænkte jeg, 'hvad sker der?'.

Først efter halvandet år, da kæresten begyndte at afskære Elif fra at besøge hendes mandlige familiemedlemmer, blev hun bevidst om den negative indflydelse, kæresten havde på hendes liv, og hun besluttede at bryde ud af forholdet.

Omfanget af den sociale kontrol er usædvanligt stort i Elifs tilfælde, men den er ikke atypisk i mit materiale. Seks af informanterne fortalte om at have været i forhold, hvor kæresten ville kontrollere, hvem de kunne se. I flere tilfælde ledte den stigende kontrol til, at kvinderne ønskede at afbryde parforholdet. Formuleringer som ,jeg ville slå op, men han ville ikke lade mig gå“ eller „det var virkelig vanskeligt at skilles med ham“ er udbredt i materialet. Otte kvinder fortæller således om forhold, som var vanskelige at komme ud af. Det 
vanskelige bestod i, at kæresten ikke anerkendte kvindens beslutning. Nogle mænd fortsatte med at opføre sig, som om de stadig var kærester med kvinderne. De ringede og talte om hverdagsting, sendte søde sms'er, smilte eller tog kvinden i hånden, når de var i det offentlige rum. Andre gange forsøgte kæresten at ændre kvindens beslutning med undskyldninger eller løfter om at ændre adfærd. Flere af informanterne er gået med til at forsøge igen, men disse genforeninger resulterede ofte i situationer, der lignede de foregående. En enkelt informant fortalte, hvordan hun til en fest kyssede en anden mand foran sin ekskæreste for at få ham til at forstå, at forholdet var forbi.

Når manden ikke anerkender kvindens beslutning, bliver det en underkendelse af hendes autoritet til at træffe en sådan beslutning. Kvinderne søger mænd, som vil anerkende dem på lige fod, men i mange interviews har jeg oplevet kvinderne beskrive tidligere partnere som værende ,liberale“ udadtil, men patriarkalske, når det kommer til parforhold i praksis. De har fortalt, at mændene ser det som en selvfølge, at kvinder uddanner sig og arbejder, flytter hjemmefra og bor alene, og de forventer, at kvinderne er seksuelt aktive. Samtidig har kvinderne oplevet, at disse mænd vil bestemme, hvem de kan se, om de fx kan gå i byen om aftenen, og detaljeret udspørger dem om tidligere seksuelle relationer og på den baggrund dømmer kvinderne. Når kvinderne møder denne underkendelse af deres autoritet, gør det dem ofte vrede, men de har ikke samme muligheder som mændene til at hævde deres ret. Suzans fortælling om et forhold, som hun havde, da hun var mellem 17 og 20 år, tydeliggør denne ulighed:

Det var virkelig hardcore. Jeg tror, vi slog op hundrede gange, eller - jeg forsøgte i hvert fald. Det var virkelig svært at slå op med ham, fordi han ikke ville. Han truede mig, hver gang vi slog op. Faktisk blev det ikke kun ved truslerne. Han fortalte alle om ting, vi havde lavet, om ting, jeg havde gjort ... Jeg var bange for ham, fordi jeg troede, at han ville sætte mig i dårligt lys. Det var jo faktisk, hvad han havde gjort ... Én gang havde vi en pause på tre-fire måneder, og jeg havde en andet forhold. Men vi havde ikke sex. Men det troede min eks, og han mente, det var klamt, og sagde, at han ville fortælle det til mine forældre. Nogle gange røg jeg pot, og det truede han også med at ville sige til mine forældre ... Men han gjorde det ikke. Han skrev bare ting som 'Suzan er en fucking luder. Tal ikke til hende’ på internettet, på sin msn, på nogle blogs og sådan. Den slags ting.

Ud over Suzan fortæller fem kvinder om at have været udsat for sladder eller have frygtet sladder. Sladder eller frygten for sladder er en magt, som mænd kan bruge til at kontrollere kvinderne. Særligt trusler om, at forældre får at vide, at deres datter er seksuelt aktiv, er et magtfuldt redskab. Med henvisning til de moralske normer om kvindelig seksuel afholdenhed indtil ægteskab påpeger flere studier, at sladder om sex før ægteskab eller formodning derom har implikationer ikke kun 
for kvinden selv, men også for hendes familie, fordi familiens omdømme afhænger af kvindens seksualitet (Ergun 2007; Amado 2004). Da mænds førægteskabelig sex ikke i samme grad som kvinders bliver betragtet som amoralsk (Ergun 2007; Yasan et al. 2009; Ozan et al. 2005; Sakalli-Ugurlu \& Glick 2003), har sladder om mænds seksualitet ikke samme følger som sladder om kvinders seksuelle relationer. I førægteskabelige parforhold i Tyrkiet tilfalder sladderens magt derfor manden. Forhold mellem ugifte tyrkiske kvinder og deres partnere er således i udgangspunktet ulige, i og med at manden har et potentielt magtmiddel, og kvinden befinder sig i en udsat position. Som illustreret kan udnyttelsen af den potentielle magt udvikle sig til, at patriarkalske normer om mandlig dominans langsomt bliver en del af parforholdene, og kvinderne underlægges social kontrol. I nogle tilfælde accepterer kvinderne den, mens de i andre tilfælde insisterer på deres autonomi og gør verbal modstand mod den sociale kontrol.

\section{Seksuel vold og kategorisering}

Kvinderne i min undersøgelse beskriver, at når de indgår i parforhold, forventes det af dem, at de er seksuelt aktive. Det forventer deres venner og deres partnere, og det forventer de selv. Men forventningen bliver i mange tilfælde en pligt, og i et parforhold med en potentielt ulige magtfordeling, er grænsen mellem at være forpligtet til noget og kunne blive tvunget til noget ikke altid klar. Mira får sin første kæreste, hun har en seksuel relation til, som 17-årig. Hun fortæller: „Nogle gange gjorde vi det, og jeg lod altid, som om jeg var glad, men jeg følte aldrig rigtig glæde - nydelse. Altså, det var næsten en forpligtelse for mig.“" Mira har svært ved at sige fra hver gang, da hun oplever sin rolle i parforholdet forbundet med en pligt til sex. Suzan beskriver sit første seksuelle forhold på samme måde: „Jeg kan ikke huske, at jeg nogen sinde nød det. Jeg mener, vi gjorde det, men specielt i sidste del af forholdet havde jeg ikke lyst. Jeg sagde, at jeg havde menstruation, eller jeg prøvede altid at finde på undskyldninger for ikke at gøre det." Eksemplerne er udtryk for, at nogle kvinder føler sig forpligtet til sex. Men er det tvang? Måske ved partnerne ikke, hvordan de skal tilfredsstille kvinderne. Eller måske vil partnerne gerne, men kvinderne kan ikke finde ud af at formulere, hvad der tilfredsstiller dem. Syv af informanterne fortæller om at have været $\mathrm{i}$ en eller flere situationer, hvor en partner ønskede sex, men hvor de ikke selv var indstillet på det. Én fortæller om at have startet et forhold, som hun selv havde seksuelle forventninger til, men hvor manden til hendes irritation gerne ville udvikle følelsesmæssige sider af forholdet først. Nogle kærester har respekteret kvindernes ønsker, mens kvinderne $\mathrm{i}$ andre tilfælde har haft vanskeligt ved at sige fra over for deres partnere, og derfor har de ladet, som om de nød sex, eller har 
forsøgt at komme med undskyldninger for at slippe. Det ulige magtforhold er en faktor, som kvinderne forholder sig til. Som i eksemplet, hvor Suzan beskrev de trusler om sladder, som hendes kæreste udsatte hende for, begrunder kvinderne i nogle tilfælde den manglende eksplicitte modstand med en frygt for, hvad kæresten kunne finde på. Hvis mændene bliver afvist mange gange eller ikke får deres vilje, kan det ende i tvang. Fire af informanterne giver udtryk for frygten herfor. Én har været udsat for voldtægtsforsøg, og to beretter om seksuel vold fra en kæreste.

Derya på 23 år er den ene informant, der havde oplevet seksuel vold. Den fandt sted $\mathrm{i}$ hendes første parforhold, da hun var 20 år og endnu jomfru. Hendes 29-årige kæreste ville gerne have sex, men Derya afviste ham mange gange, hvilket ledte til store diskussioner. Derya fortalte mig: ,Jeg var så flov i disse diskussioner. Han blev ved at spørge mig 'Hvorfor? Hvorfor? Hvorfor vil du ikke have mig? Elsker du mig ikke!?'. Og jeg forsikrede ham, at jeg elskede ham. 'Hvorfor vil du så ikke have mig!?’ råbte han. Og jeg vidste ikke hvorfor.“ Kæresten havde således en forventning til Derya om at være villig til sex. Derya nød at give kærlighed og tilsvarende modtage opmærksomhed fra kæresten, og selvom hun fortalte mig, at hun dengang gerne ville af med sin mødom, var hun nervøs for sin seksuelle debut og følte sig ikke klar til den. Ved at sætte kærlighed lig med sex - og muligvis også ved at råbe - gjorde kæresten Derya usikker på, hvad forholdet indebar: om kærlighed var lig med sex, og om hun var forpligtet til sex i forholdet? Flere af informanterne udtrykte lignende usikkerhed om, hvad de havde lyst til, var forpligtet til og kunne blive tvunget til. I Deryas tilfælde gik forholdet i stykker, fordi kæresten ikke ville undvære et egentlig seksuelt forhold:

Han ringede til mig efterfølgende, og vi mødtes et par gange. En dag kom han hjem til mig, og vi begyndte at nusse. Han tvang mig til oralsex. Jeg havde gjort det før, men havde gjort det uden at have lyst. Jeg kunne ikke lide oralsex. Hverken at give det eller at få det. Jeg følte mig genert ... Men han ville have det, og jeg gjorde det ikke. Den nat brugte han vold. Han havde aldrig brugt vold før, så hvorfor nu? Den nat gjorde han det hårdt. Han ville have oralsex. Han rev i mit hår. Jeg var så fremmed over for disse ting. Jeg havde ikke haft andre mænd end ham, så da vi var sammen igen, forventede jeg den samme ømhed, som han tidligere havde vist ... Han prøvede at komme op i mig. Den dag var det sidste dag i min menstruation. Han så det og spurgte, om jeg havde menstruation. Jeg svarede ja, og han blev irriteret og rejste sig. I spejlet så han, at hans krop og hænder var røde efter mig, og han begyndte at råbe: 'Hvornår stopper det her? Hvordan kan du gøre det? Du bløder. Du er syg!' Jeg var virkelig chokeret og prøvede at undskylde. Han gik for at vaske sig. Jeg var så flov. Den aften gik vi fra hinanden.

Da de tidligere var gået fra hinanden, fordi kæresten ikke var tilfreds med deres (manglende) sexliv, var presset for at have et seksuelt forhold nu endnu større. 
Selvom Derya satte sig imod, da kæresten overskred hendes grænser, og selvom han brugte tvang, skammede hun sig. Hun oplevede situationen som selvforskyldt og forklarer: „Hvorfor skete det? Fordi jeg var jomfru, troede jeg. Og jeg havde det virkelig dårligt." Den skam, Derya følte, var forbundet med, at hun i første omgang havde sagt ja til at indgå $\mathrm{i}$ et parforhold, hvor hun vidste, der lå en forventning om seksuel aktivitet. Hun begrunder således ekskærestens vold med sin seksualitet eller rettere sin manglende villighed til at indgå en fuldbyrdet seksuel relation.

Også Leyla har oplevet seksuel vold. Den fandt sted, da hun var 24 år, og i lighed med Derya oplevede hun, at hendes kæreste udviste en stigende dominans, som hun til at begynde med accepterede. Hun beskrev, hvordan deres normale sexliv udviklede sig til et punkt, hvor hun ikke længere ville være med:

Han pressede mig. Pressede mig ud i meget blottede positioner. Han ville gøre det bagfra. Jeg sagde nej, jeg ville ikke have det. Det gjorde virkelig ondt, og han prøvede virkelig. Og så en dag tog han mit hår - og trak. Jeg begyndte at græde. 'Jeg er ikke din luder, du kan ikke gøre det sådan her,' sagde jeg, 'jeg vil ikke.' Det gjorde mig så ked af det. Jeg elskede ham stadig. Han var ikke normalt sådan, han var virkelig okay ... Han gjorde det ikke igen, men det ødelagde noget i vores forhold.

Af Leylas udtalelse kan udledes, at hun forstår et parforhold som et ligeværdigt forhold, hvor begge parters ønsker respekteres. Tilfælde, hvor manden seksuelt dominerer og dikterer, opfatter hun som en relation mellem en kunde og en prostitueret. I et teoretisk perspektiv er vold med til at opretholde de kategorier, som er på spil:

Mænds vold mod kvinder er udtryk for en samfundsmæssig kønsulighed. Volden udøves først og fremmest af de mere magtfulde, og den bruges til at kontrollere og disciplinere de mindre magtfulde. Vold er den ultimative form for kategorisering, idet den bruges til at sætte/banke den anden part på (rette) plads i tilfælde af, at hun ikke selv kender grænserne eller ligefrem udfordrer dem (Danneskiold-Samsøe, Mørck \& Sørensen 2011:37).

Set i dette lys har volden den funktion, at den tydeliggør bestemte kategorier og grænser. I tilfældet med unge mænd og kvinder, som indgår i førægteskabelige seksuelle forhold i Tyrkiet, er der ikke altid klarhed om kategorierne. Dette bliver tydeligere, hvis vi ser på definitioner af ordene ,pige“ og „kvinde“ på tyrkisk. Ifølge det officielle tyrkiske sprognævn er en pige - k1z - defineret som ,pigebarn, jomfru“(TDK 2010a). En kvinde - kadın - er defineret som ,et voksent kvindeligt menneske, en gift pige, husmor, kone“" (TDK 2010b). Hvad der adskiller en pige fra en kvinde, er således hendes seksuelle og ægteskabelige status. Flere studier 
peger i denne forbindelse på, at ugifte piger, der har sex, derfor betragtes som amoralske eller promiskuøse (fx Altinay 2000; Durakbasa 1998; Özyegin 2009; Saktanber 1995). Mændenes brug af vold og social kontrol kan i dette perspektiv forstås som et middel til at tydeliggøre bestemte kategorier, og hvilke forpligtelser og rettigheder der knytter sig til dem.

Özyegins studie af mødomsopfattelser blandt universitetsstuderende i Istanbul viser imidlertid, at der eksisterer en tredje kategori nemlig „motor“, som er en betegnelse for kvinder, der har mange og skiftende seksuelle relationer før ægteskab (Özyegin 2009:114). Denne kategori passer på mine informanter, men det er en negativt ladet kategori, der bruges til at betegne kvinder med lav moral. Måske netop derfor stødte jeg ikke på denne kategori under mit feltarbejde. Derimod betegner mine informanter sig selv som ,kvinder med liberal seksualitet“. Betydningen af seksualitet bliver således omdefineret som et alternativ til kvinder med lav moral, idet seksualitet bliver en måde at praktisere et tilhørsforhold til en vestlig orienteret overklasse på (Tafdrup 2011:30-45).

Dette er en omdefinering, kvinderne selv foretager, men det er også en omdefinering, som deres jævnaldrende mandlige venner og kærester medvirker til gennem forventning om og deltagelse i kvindernes seksuelle aktivitet. Min viden om de mænd, som kvinderne har haft forhold til, er begrænset, men mit generelle indtryk er, at mændene er uddannede og kommer fra øvre middelklassehjem ligesom kvinderne selv. I fortællingerne om vold begrunder kvinderne ofte mændenes handlinger med henvisning til deres familiemæssige baggrund. Ofte beskriver kvinderne ekskærestens hjem som domineret af patriarkalske normer, hvor faderen var autoriteten og moderen undertrykt. Kvindernes henvisninger til kulturelle forhold fungerer således som undskyldning for mændenes adfærd. Kvindernes tavshed er dog paradoksal. På den ene side forstår de sig selv som selvberoende kvinder med integritet, og på den anden side forbliver de tavse, når deres partnere udnytter dem eller udsætter dem for fysisk vold eller social kontrol. I det følgende afsnit vil jeg se nærmere på den bredere kontekst, som magtmisbruget finder sted $i$, for at få en bedre forståelse af denne tavshed.

\section{Når tavsheden brydes: fornægtelse, vrede og skam}

Som beskrevet forventer både kvinderne og deres partnere, at parforhold udvikler sig seksuelt, men der er uklarhed om, hvad denne forventning betyder. Er det et løfte? Er det en pligt eller en ret? Og hvad er mulighederne, hvis forventningen ikke indfries? Kvinderne er ikke „de pæne piger“, der beskytter deres mødom til ægteskabet, men de forstår heller ikke sig selv eller deres veninder som promiskuøse. Når de som unge kvinder har seksuelle forhold i et samfund, hvor 
det ikke er normen, medfører det, at de er usikre på deres egen rolle i disse relationer. Her er det værd at bemærke, at kvinderne er relativt unge nemlig gennemsnitlig 21 år, da eksemplerne med tvang finder sted, og deres viden om seksualitet og parforhold er begrænset. Der er obligatorisk seksualundervisning i Tyrkiet, men ofte modtager de unge ikke undervisningen, og de informanter, der faktisk har haft en times undervisning, fortæller, at det i praksis bestod af uddeling af bind til piger og kondomer til drenge; ingen forklaringer og ingen spørgsmål. Informanterne fortæller, at deres viden om seksualitet og parforhold stammer fra tv, internet, pornofilm og egne erfaringer. Til trods for at der i venskabsgrupperne tales om sex, så foregår det på et overfladisk plan, hvor personlige erfaringer ikke inddrages. Kun med enkelte veninder deles personlige oplevelser. Men veninderne er ofte lige så uerfarne og uvidende som kvinden selv. Denne tendens ses også $i$ et andet studie blandt universitetsstuderende (Ozan et al. 2005). Studiet viser, at venner samt bøger, magasiner og fjernsyn er de primære kilder til de unges viden om seksualitet, og at skole og lærere er de mindst brugte informationskilder (op.cit.173, 178). I mit studie anser informanterne heller ikke læger som potentielle kilder til information. Flere har oplevet læger som formanende eller fordømmende, og en fortalte, at hendes læge ville videregive sexrelaterede oplysninger til hendes forældre, hvis hun ikke selv gjorde det. Netop relationen mellem de unge og deres forældre er afgørende for at forstå, hvorfor tavsheden om førægteskabelig sex opretholdes.

I den tidligere nævnte undersøgelse om universitetsstuderende fremgår det, at mødre er en vigtig kilde til information blandt kvindelige studerende. Studiet viser imidlertid også, at kvinderne primært har opsøgt viden om forandringer i puberteten, graviditet og fødsel og i mindre grad om kønssygdomme, prævention og samleje (Ozan et al. 2005). I mit studie har kun ganske få talt med deres forældre om seksualitet, og da kun i korte bemærkninger som „du bør ikke være seksuelt aktiv, før du bliver gift“ eller „husk at bruge beskyttelse“. Forældrene har ofte været formanende eller pinligt berørte, og kvinderne ser ikke forældrene som en kilde til viden eller rådgivning. Lignende fund ses i en anden undersøgelse, hvor der peges på, at kvindelig førægteskabelig seksualitet ignoreres i familien af frygt for at skade familiens omdømme (Kayir i Ergun 2007:2). Ud af mine 15 informanter er der kun to, der ved, at deres forældre åbent accepterer, at de er seksuelt aktive. Mit kendskab til kvindernes forældre og denne generation er begrænset, og samtidig varierer informanternes familiemæssige baggrunde meget. Hvor forældrenes indbyrdes forhold nogle gange beskrives som præget af ligeværdighed og kærlighed, beskriver andre informanter deres barndomshjem som præget af enten moderens eller faderens dominans. Ingen kommer fra meget religiøse hjem, men hjemmene er typisk præget af en nationalistisk ideologi, 
hvor det forventes, at kvinder tager uddannelse og har erhvervsarbejde, og hvor forældrene accepterer, at deres døtre har kærester eller flytter hjemmefra. Når det kommer til døtrenes seksualitet, mødes kvinderne imidlertid ikke med samme anerkendelse. Ved at undgå at tale om seksualitet eller ved eksempelvis at rede op til en datters kæreste $i$ et separat rum, hvis kæresten skal overnatte $i$ familiens hjem, kan forældrene lade, som om døtrene er jomfruer. Og tilsvarende konfronterer kvinderne heller ikke deres forældre med deres seksualitet. Özyegin bruger betegnelsen ,jomfrufacader“ om dette spil mellem døtre og forældre (Özyegin 2009).

Hvis kvinderne ikke har lyst til at dele oplevelser med deres forældre, og derfor ikke taler med dem herom, er det uproblematisk. I min forståelse består det problematiske i, at de unge kvinder ikke føler, at de kan komme til deres forældre, og at de ikke har en anden person med autoritet og erfaring, som de har tillid til, i tilfælde af at de har behov for det eller været udsat for krænkelser. Derya har kun talt med sin mor om et seksuelt relateret emne én enkelt gang. Det var en dag, hvor hun var på besøg i familiens hjem, og hun besluttede at forsøge at rykke lidt ved moderens forestillinger ved at fortælle, at hun sov sammen med sin kæreste og derved implicit havde sex:

Sidste år besluttede jeg mig for at forklare det til min mor. Det var en meget radikal opførsel for mig. Fordi min mor tænker som min far, og selvom årene er passeret, tænker de stadig det samme [jeg lavede mad, og bedste sov i samme rum]. Og jeg fortalte det [til min mor], pludseligt. Og hun var chokeret: 'Hvordan kan han sove hos dig!?' Jeg sagde: 'Det gør han'. Hun sagde: 'Sover han i din seng.' Jeg sagde ja. Hun sagde: 'Sover I sammen!?'. Jeg svarede ja, og hun rødmede og var virkelig chokeret. Men jeg prøvede ikke at få hende til at falde ned ... Men jeg tror, at min mor stadig tror, jeg er jomfru, fordi det er, hvad hun ønsker at tro. Fordi - du ved - i Tyrkiet er der ingen mellemvej: Enten er du jomfru, eller du er en luder. Derfor ønsker min mor, at tro det [at jeg er jomfru]. Hvis jeg mister min mødom, er jeg en luder.

Derya henviser til luder-madonna-dikotomien, som forskning da også fremhæver som dominerende i Tyrkiet. Den indebærer, at en kvinde enten betragtes som uanstændig eller som ærbar (se fx Saktanber 1995; Parla 2001). Moderens reaktion tydeliggør styrken af de moralske normer, som seksuelt aktive ugifte kvinder er oppe imod, idet hun hverken ønsker at blive konfronteret med eller at anerkende, hvad datteren fortæller hende. Derya har aldrig siden talt med sin mor om et seksuelt relateret emne, og hun har heller ikke fortalt om den vold, hun var udsat for i sit første forhold. Tilsvarende har hverken Elif eller Leyla talt med deres forældre om de problemer, de havde i deres forhold. Elif har én nær veninde, som hun har delt historien om indespærring med, og Leyla har to veninder, som hun delte voldsoplevelsen med på daværende tidspunkt. Politi eller 
anden myndighed som fx en lærer eller læge er heller ikke blevet kontaktet, og der er ingen autoritet, kvinderne tør betro sig til. Generelt er det sådan, at kvinderne har én eller to nære veninder, som de kan udveksle erfaringer med.

Årsagen til, at kvinderne føler, at de ikke kan tale med deres forældre, kan spores tilbage til de moralske normer om kvindelig seksualitet og ære. Her er det værd at bemærke, at ordet „ære“ på dansk kun er ét ord, mens man på tyrkisk har mindst ${ }^{3}$ to ord: „namus" og „şeref". Namus bliver blandt andet brugt om både omdømme, loyalitet, ærlighed og sexære. Omend det er omdiskuteret, hvad namus præcist indebærer, og hvorvidt både mænd og kvinder kan have det, så er der blandt forskere enighed om, at namus refererer til kvinders seksuelle ære, det vil sige, omhandler pigers jomfruelighed indtil ægteskab (Kragh 2010:20614). Şeref har også flere betydninger, fx udmærkelse og gæstfrihed, individuel belønning og en gruppes omdømme. Centralt i forståelsen af şeref er, at det henviser til en gruppes (eksempelvis en families) ære og denne gruppes relation til andre grupper. Således er şeref et udtryk for statusposition. En gruppes peref er afhængig af de enkelte medlemmers ære, herunder en kvindes namus. Det vil sige, at hvis en kvindes namus plettes, skades gruppes şeref (ibid.).

Disse forskellige forståelser af ære kaster lys over kvindernes tavshed om førægteskabelig sex. Hvis en kvinde har sex uden for ægteskab, mister hun ikke kun sin egen ære (i Deryas ord „bliver en luder“), men også familiens ære. Denne relation mellem kvindens handlinger og familiens ære er sjældent noget, informanterne fortæller eksplicit om, men den udgør et implicit vilkår, der bliver synligt, når kvinderne fx beskriver, hvordan deres forældre reder op til kæresten $i$ et separat rum, ikke finder en kæreste passende som ægtemand eller benægter døtrenes seksualitet.

30-årige Zehra er en af de få informanter, der italesatte relationen mellem sine handlinger og familiens ære. Som 24-årig besluttede hun at forlade sine forældres hus i Izmir for at flytte til Istanbul sammen med en kæreste, som hun havde haft gennem to år. Da hun fortalte sin far om planerne, blev han så vred, at han sagde, at hvis hun forlod hjemmet uden at være gift, ville han slå hånden af hende. Zehra og hendes kæreste forlovede sig derfor, men efter et stykke tid gik forholdet i stykker. I flere år forsøgte Zehra at etablere et hjem i Istanbul, fik en høj uddannelse, job og hjalp sin søster med at etablere sig i Istanbul, da hun måtte flytte dertil for at studere. På trods af at der er gået flere år, og at Zehra forsøger at udmærke sig på forskellig vis, har faderen stadig ikke anerkendt hende. Med en stemme af sorg og ydmygelse forklarede hun:

Det er virkelig hårdt - 'hvordan kunne du?'. Du føler dig så ydmyget over for dine venner og din familie. Min far har altid stolet på mig. Jeg har aldrig forsøgt at gøre ham vred; jeg har gjort mit bedste ... Og - forstår du - også for hans [faderens] familie er det ydmygende. 
Kvinderne skal således ikke kun beskytte deres egen ære, men også deres families ære. Dette er afgørende for, at kvinderne ikke kan dele seksuelt relaterede oplevelser med deres familie, herunder at de har været udsat for krænkelser.

\section{Tavshedens paradokser}

Kvindernes måde at tænke, forstå og handle på kommer blandt andet af de moralske forventninger, der er til kvinders seksualitet i den bredere sociokulturelle kontekst og dermed også i deres familier og blandt deres jævnaldrende. Blandt deres jævnaldrende skal de imidlertid balancere mellem på den ene side at vise sig som „,iberale kvinder" ved at være seksuelt aktive, og på den anden side kan de møde fordømmelse, hvis de er for „liberale“ seksuelt. Dette forklarer Selma. Hun havde sex første gang med en mand, som hun knap nok kendte og ikke forestillede sig at starte et forhold til. Hun var sammen med ham med det formål at komme af med sin mødom. Da hun som 18-årig fortæller en senere kæreste om det, oplever hun moralsk fordømmelse:

Han begyndte at sige ting som 'hvordan kunne du gøre det? Det er så amoralsk!'. Pludselig sagde han den slags ting om mig. Jeg havde aldrig tænkt på mig selv som en amoralsk person ... Jeg følte mig flov. Jeg havde aldrig fortrudt, at jeg gav min mødom til en eller anden fyr. Men han fik mig til at have det dårligt med det og med mig selv. Jeg ved ikke, hvad der skete den nat, men han fik overtaget. Jeg kan stadig ikke forstå det. Jeg skammede mig sådan.

At praktisere et tilhørsforhold til en overklasse gennem seksuel aktivitet uden at blive fordømt som en kvinde med lav moral, er tydeligvis en vanskelig balancegang for mine informanter.

Den modsætningsfyldte situation mellem forskellige moralske værdier og forventninger fra forældre og jævnaldrende, som kvinderne befinder sig i, resulterer i tavshed. Lektor i psykologi Zeynep Alat (2006) har studeret mediernes fremstilling af vold mod kvinder i Tyrkiet, og hun konkluderer, at medierne er medvirkende til fastholdelse af den dominerende kønnede logik, som underminerer kvindens integritet. Alat viser, hvordan medierne benytter en retorik, der mistænkeliggør kvinder, hvorved de kommer til at fremstå som medvirkende til de overgreb, de udsættes for, hvormed overgrebene retfærdiggøres (ibid.). Måske er det noget tilsvarende, som mine informanter frygter, når de forbliver tavse om deres førægteskabelige seksuelle oplevelser? Selv hvis deres rettigheder krænkes, kan de ikke tale om det, fordi de i udgangspunktet har sagt ja til seksuel omgang, hvorefter såvel andre som de selv kan betragte situationen som selvforskyldt. 
Omfanget af vold i Tyrkiet kan være vanskeligt at opgøre præcist. Et studie anslår, at 39 procent af landets kvinder har været udsat for fysisk vold, 15 procent for seksuel vold og 44 procent for psykisk vold (se Danneskiold-Samsøe, Mørck \& Sørensen 2011:368, der henviser til tyrkisk forskning), men et andet anslår, at 35,1 procent har været udsat for fysisk vold, og 14 procent har været tvunget til seksuel omgang (ibid.). Forskerne peger dog på, at tallene formentlig er undervurderede, idet mange voldstilfælde ikke bliver rapporteret. En forklaring herpå kan være manglen på mulige instanser at melde volden til eller en forventning om ikke at modtage støtte i tilfælde af anmeldelse (op.cit.366). En anden forklaring kan være, at 30 procent af kvinderne i Tyrkiet mener, at vold i hjemmet er et privat familieanliggende (Alat 2006:297). Gennemgående forklarer forskerne de manglende anmeldelser af overgreb med henvisning til de dominerende kønnede moralske holdninger og værdier i Tyrkiet, der indebærer en underordning af kvinden, der blandt andet betyder, at hendes krop først tilhører familien og siden hendes ægtemand (ibid.; Danneskiold-Samsøe, Mørck \& Sørensen 2011:368).

Studierne af vold i Tyrkiet fokuserer på vold i familien, og jeg har ikke kendskab til studier, der behandler kærestevold mod ugifte kvinder. Derfor er det vanskeligt at sige, hvor udbredt vold er blandt seksuelt aktive unge i overklassen. I mit materiale beskriver syv informanter episoder, hvor de har været udsat for social kontrol, syv har følt sig udnyttet enten seksuelt eller følelsesmæssigt, og fire har været udsat for fysisk partnervold, seksuel vold eller voldtægtsforsøg. Endvidere har tre været udsat for trusler, seks har frygtet en kæreste eller sladder. Otte har haft vanskeligt ved at komme ud at et uønsket parforhold, og fire har været udsat for seksuelle bebrejdelser eller fornærmelser. Samlet har $12 \mathrm{ud}$ af de 15 informanter oplevet en eller flere af ovenstående voldsformer. De resterende tre beskriver ikke krænkende situationer, men har alle været generet af jalousi i et parforhold.

Kvindernes tavshed om disse episoder og deres førægteskabelige seksuelle liv generelt er paradoksalt. De giver eksplicit udtryk for selv at ville styre deres liv. De ønsker at blive anerkendt af deres familie, venner og partnere som autonome individer, der har ret til at træffe betydningsfulde beslutninger om $\mathrm{fx}$ at være seksuelt aktiv, flytte hjemmefra eller at være ugift. Men når de risikerer at møde moralsk fordømmelse ved at italesætte disse beslutninger, forholder de sig tavse. Tavsheden er imidlertid med til at opretholde de rådende moralske værdier og holdninger. Den må således brydes, hvis der skal udvikle sig større lighed mellem kønnene i Tyrkiet. 


\section{Noter}

1. Det materiale, som jeg indsamlede under feltarbejdet, danner baggrund for denne artikel. Informanternes navne er synonymer.

2. Jeg har valgt at bruge formuleringen ,seksuelt aktiv“, da en enkelt informant er ,teknisk jomfru“, men har været seksuel aktiv i mange år uden penetration.

3. Mindst to henviser til, at flere ord kan relateres til det danske ord ære: haysiyet (agtelse), gurur (stolthed for en selv), onur (stolthed i livet) og saygi (respekt) er alle æresrelaterede tyrkiske ord (Kragh 2010:206-8).

Søgeord: kvindelig seksualitet, førægteskabelig sex, vold, Istanbul, unge, moral

\section{Litteratur}

Alat, Zeynep

2006 News Coverage of Violence Against Women: The Turkish Case. Feminist Media Studies 6(3):295-314.

Altinay, Ayse G.

2004 Talking and Writing our Sexuality: Feminist Activism on Virginity and Virginity Tests in Turkey. In: P. Ilkkaracan (ed.): Women and Sexuality in Muslim Societies. Istanbul: Women for Women's Human Rights.

Amado, Liz Ercevik (ed.)

2004 Sexual and Bodily Rights as Human Rights in the Middle East and North Africa.

Conference report. Istanbul: Women for Women's Human Rights - New Ways.

Cindoglu, Dilek

1997 Virginity Tests and Artificial Virginity in Modern Turkish Medicine. Women's Studies International Forum 20(2):253-61.

Danneskiold-Samsøe, Sofie, Yvonne Mørck \& Bo Wagner Sørensen

2011 „Familien betyder alt“. Vold mod kvinder i etniske minoritetsfamilier.

Frederiksberg: Frydenlund.

Durakbasa, Ayse

1998 Kemalism as Identity Politics in Turkey. In: Z.F. Arat (ed.): Deconstructing images of "the Turkish woman". New York: St. Martin's Press.

Ergun, Mehmet A.

2007 Social Determinants of Attitudes towards Women's Premarital Sexuality among Female Turkish University Students. Sex Cult 11:1-10.

HRW, Human_Rights_Watch

2011 "He Loves you, He Beats you": Family Violence in Turkey and Access to Protection. Hentet fra http://www.hrw.org/reports/2011/05/04/he-loves-you-hebeats-you.

Ilkkaracan, Pinar

2010 Islam and Women's Sexuality: A Research Report from Turkey. In: M. Hunt, P. Jung \& R. Balakrishnan (eds.): Good Sex: Feminist Perspectives from the World's Religions. New Jersey: Rutgers University Press. 
Kragh, Lotte

2010 Kampen om anerkendelse, spillet om ære. Doktordisputats. København: Institut

Lundgren, Eva for Psykologi, Københavns Universitet.

2004 Våldets Normaliseringsprocess. Linköping: ROKS.

Ozan, Sema, Sahbal Aras, Semih Semin \& Esmahan Orcin

2005 Sexual Attitudes and Behaviors among Medical Students in Dokuz Eylul University, Turkey. The European Journal of Contraception and Reproductive Health Care 10(3):171-83.

Özyegin, Gul

2009 Virginal Facedes: Sexual Freedom and Guilt among Young Turkish Women.

European Journal of Women's Studies 16(2):103-21.

Parla, Ayse

2001 The "Honor" of the State: Virginity Examinations in Turkey. Feminist Studies 27: 65-88.

Sakalli-Ugurlu, Nuray \& Peter Glick

2003 Ambivalent Sexism and Attitudes toward Women who Engage in Premarital Sex in Turkey. The Journal of Sex Research 40(3):296-302.

Saktanber, Ayse

1995 Women in the Media in Turkey: Free, Available Women or the Good Wife and

Selfless Mother. In: S. Tekeli (ed.): Women in Modern Turkish Society: A Reader. London: Zed Books.

Tafdrup, Ida

2011 Et antropologisk studie af kønsidentitet blandt ugifte kvinder i Istanbuls universitetsmiljø: At være pige og kvinde og det midt imellem. Specialerække 616. København: Institut for Antropologi, Københavns Universitet.

TDK, Türk Dil Kurumu (det officielle tyrkiske sprognævn)

2010a http://tdkterim.gov.tr/bts/?kategori=verilst\&kelime $=\mathrm{a} \%$ FDz\&ayn=tam (hentet 1 . juni 2010).

$2010 \mathrm{~b} \quad \mathrm{http} / /$ tdkterim.gov.tr/bts/?kategori=verilst\&ayn=bas\&kelime=kadın (hentet 1. juni 2010).

WHO, World Health Organization

2002 World Report on Violence and Health: Summary. Geneve: World Health Organization.

WWHR, Women for Women's Humans Rights

2010 The Shadow NGO Report on Turkey's Sixth Periodic Report to the Committee on the Elimination of Discrimination against Women. The Executive Committee for NGO Forum on CEDAW - Turkey, Women's Platform on the Turkish Penal Code. New York: 46th Session of CEDAW.

Yasan, Aziz, Altan Essizoglu \& Ejder Akgün Yilderim

2009 Predictor Factors Associated with Premarital Sexual Behaviors Among University Students in an Islamic Culture. International Journal of Sexual Health 21:145-52. 